\title{
Flyway evolution is too fast to be explained by the modern synthesis: proposals for an 'extended' evolutionary research agenda
}

\author{
Theunis Piersma
}

Received: 3 May 2011/ Accepted: 26 May 2011/Published online: 11 June 2011

(C) The Author(s) 2011. This article is published with open access at Springerlink.com

\begin{abstract}
In this paper, I argue that to fully grasp the generation and maintenance of variation in the migratory phenotypes of (shore-)birds we need to expand our scientific search image and include developmental processes and non-genetic pathways of inheritance in the explanatory frameworks. Traditionally, studies of micro-evolution of migratory phenotypes were restricted to comparative studies on migratory versus non-migratory taxa, and artificial selection and heritability experiments on quantitative behavioural traits related to migration. Such studies had a focus on the genetic axis of inheritance and were restricted to songbirds. In avian groups such as the shorebird families Scolopacidae and Charadriidae, all but a few island species are migrants, which precludes comparative studies at the species level. Like other taxa, shorebirds have geographically separate breeding populations (either or not recognized as subspecies on the basis of morphological differences) which differentiate with respect to the length, general direction and timing of migration, including the use of fuelling at staging sites and the timing of moult. However, their breeding systems preclude artificial selection and heritability experiments on quantitative traits. This would seem to limit the prospects of evolutionary analysis
\end{abstract}

Communicated by F. Bairlein.

\section{T. Piersma}

Animal Ecology Group, Centre for Ecological and Evolutionary Studies (CEES), University of Groningen, P.O. Box 11103, 9700 CC Groningen, The Netherlands

\section{T. Piersma ( $\square)$}

Department of Marine Ecology,

Royal Netherlands Institute for Sea Research (NIOZ),

P.O. Box 59, 1790 AB Den Burg, Texel, The Netherlands

e-mail: theunis.piersma@nioz.nl until one realizes that the speed of evolutionary innovation in shorebird migratory life-histories may be so fast as to necessitate other avenues of explanation and investigation. According to our best current estimates based on mitochondrial gene sequence variation, in Red Knots Calidris canutus considerable phenotypic variation has evolved since the Last Glacial Maximum ca. 20,000 years ago, to the extent that six subspecies are currently recognized. This would be too short a time for the origin of the qualitatively and quantitatively distinct and non-overlapping traits to be explained by random point mutations followed by natural selection, although we cannot dismiss the possibility of previously unexpressed (standing) genetic variation followed by selection. I argue that, to understand the flyway evolution of such shorebirds in the 'extended' evolutionary framework, we need to give due attention to developmental versatility and broad-sense epigenetic evolutionary mechanisms. This means that experimental studies at the phenotypic level are now necessary. This could involve a combination of observational studies in our rapidly changing world, common garden experiments, and even experiments involving global-scale displacements of particular migratory phenotypes at different phases of development. I provide suggestions on how such experiments could be carried out.

Keywords Calidris canutus - Common garden experiment - Epigenetic - Extended synthesis .

Migration $\cdot$ Shorebirds

\section{Introduction}

Most of what has been written about the evolution of bird migration (Alerstam et al. 2003) has had a strong focus on 
the (micro-)evolution of migration traits in songbirds (e.g. Berthold and Querner 1981; Berthold 1995; Able and Belthoff 1998) and on comparative studies between migrant and non-migrant taxa (e.g. Zink 2002; Helbig 2003; Outlaw et al. 2003; Rappole et al. 2003; Salewski and Bruderer 2007). The portfolio includes studies of artificial selection and heritability experiments on quantitative behavioural traits related to migration such as the duration and timing of migratory restlessness (e.g. van Noordwijk et al. 2006; Pulido 2007; Pulido and Berthold 2010). As impressive and as valuable all these studies are, I have found myself frustrated when applying the supposedly unifying but passerine-biased frameworks to the thinking about flyway evolution in the group of birds that I am most familiar with, the shorebirds, and especially the family of sandpipers Scolopacidae (Piersma et al. 1996) and the plover family Charadriidae (Piersma and Wiersma 1996).

Here is why. All but a few (island) species of shorebirds are migrants which precludes comparative studies on closely-related migratory and non-migratory species. Like other taxa, shorebirds do have geographically separate breeding populations (which may or may not be recognized as subspecies on the basis of morphological differences; Engelmoer and Roselaar 1998) which differentiate with respect to the length, general direction and timing of migration, including the use of fuelling at staging sites and the timing of moult. However, the peculiarities of their breeding systems preclude studies of inheritance of quantitative traits such as migratory restlessness. Importantly, the traits on the basis of which subspecies are distinguished are distinct and do not overlap, i.e. they seem to show evolutionary novelty rather than the gradual variation on which natural selection can work (van Noordwijk et al. 2006).

All these impossibilities may actually turn out to be a blessing in disguise as it forces us to think about evolutionary mechanisms of flyway evolution other than those involving only genes and the genetic inheritance pathway. This is especially relevant, as in shorebirds extant trait variation seems to have evolved over very short time periods relative to the evolutionary timescales necessary for new point mutations and subsequent natural selection to live out their creativity (Barrett and Schluter 2008). For example, studies of neutral markers in the mitochondrial genome of Red Knots Calidris canutus have indicated that the outspoken global flyway pattern that we observe today (Fig. 1) may be of recent, post-Pleistocene, origin (Buehler and Baker 2005; Buehler et al. 2006). The discontinuous circumpolar breeding range of Red Knots incorporates breeding areas of at least six populations that are morphologically sufficiently distinct to count as subspecies (Tomkovich 1992, 2001), but which appear to have diversified recently from a small founder population that survived the Last Glacial Maximum at approximately 20,000 years ago. The subspecies are certainly distinct when it comes to their migratory trajectories and the seasonal timing of their movements (Piersma et al. 2005; Buehler and Piersma 2008; Piersma 2007). For the classic evolutionary mechanisms of random point mutations and gene selection mechanisms to explain the divergence of qualitatively and quantitatively distinct and non-overlapping traits, populations and time since divergence have, simply, been too small (Haldane 1957; Nunney 2003).

In this brief contribution, I aim to propose that to understand the flyway evolution of such shorebirds we need an 'extended' evolutionary framework with a mindset that is prepared to consider the many creative possibilities of individual development (Turner 2007; Badyaev 2011a, b) and broad-sense epigenetic evolutionary mechanisms (Jablonka and Lamb 2006). In addition to further genomic work to establish timelines of divergence in different clades of long-distance migrants, I will argue that we need intensive observational studies in our rapidly changing world and experimental studies at the phenotypic level.

\section{Microevolution of contrasting seasonally changing phenotypes}

Red Knots and other long-distance migrating shorebirds show amazing seasonal variation in phenotype. For example, body mass is doubled before take-off on flights of $5,000 \mathrm{~km}$ or more, and halved during the continuous flight which may take up to 10 days (Battley et al. 2000; Gill et al. 2009). These changes involve great modifications in fat stores, but also include modifications to most organs (other than the kidneys, the lungs and the brain; Piersma et al. 1999; Battley and Piersma 2005; Piersma and van Gils 2011). On top of all these seasonal variations, shorebirds also adjust phenotypes to unpredictable environmental changes in food type, climatic conditions and disease pressure (Vézina et al. 2006, 2010; Buehler et al. 2008a, b).

If some of today's flyways were indeed established within the past 1,000 years (as in the split between the Red Knot subspecies rufa and islandica; Buehler et al. 2006), then it follows that it is possible for very drastic changes in phenotype (body size, plumage characters, annual cycle characteristics) to occur within 100 generations (Fig. 2). The subspecies rufa and islandica are both relatively largebodied (Tomkovich 1992), but despite its name, rufa is the palest subspecies, whereas islandica is among the darkest (Buehler and Piersma 2008). While rufa has the longest seasonal migration, commuting between the sub-Antarctic during the nonbreeding season and the Canadian High Arctic during the breeding season (see Fig. 1), islandica 


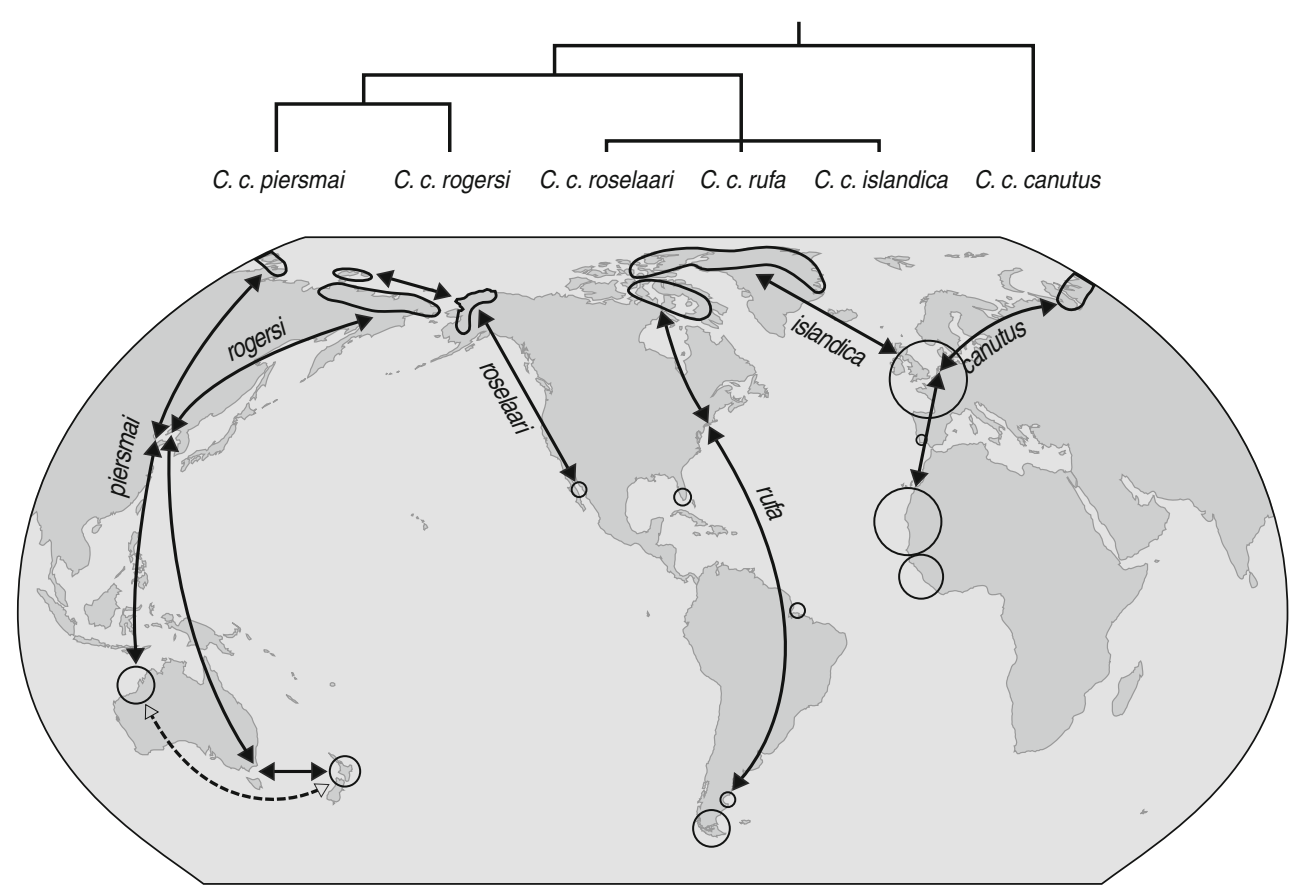

Fig. 1 The worldwide flyways of six morphologically distinct subspecies of Red Knot Calidris canutus. Polygons in the Arctic depict breeding ranges; circles depict principal wintering areas with the diameters of circles indicating relative numbers of birds. Arrows depict north- and southward migration routes and use of en route sites. Projected above the contemporary distribution of Red Knots is a 'tree' summarising the phylo-geographic structure as presently

which breeds nearby has the shortest migration of all the subspecies. The two subspecies differ with respect to departure directions, the timing of fuelling, flight and moult episodes, seasonal disease pressures (Buehler et al. 2009) and diet—especially during northward migration (Piersma et al. 2005).

Interestingly, and arguing for a hard-wired programming of annual cycles, the seasonal phenotypic changes shown outdoors are maintained by Red Knots and Great Knots Calidris tenuirostris kept in photoperiodic- and temperature-constant indoor environments (Piersma 2002; Reneerkens et al. 2007; Piersma et al. 2008). When adult birds of the contrasting subspecies islandica and rufa are brought into similar conditions in captivity, they show very distinct annual cycles (Fig. 3). Birds of the islandica subspecies typically show a single mass peak in spring and carry their alternate plumage relatively briefly (see also Piersma 2002; Reneerkens et al. 2007), whereas rufa Knots in captivity show two mass peaks and carry the alternate plumage much longer. If the divergence of the flyways of rufa and islandica Knots really represent historic rather than prehistoric phenomena, this raises the compelling question as to how shorebirds could adjust migration-related traits so quickly. understood (Buehler and Baker 2005). Note that the subspecies rufa and islandica are impossible to tell apart on the basis of neutral genetic markers yet show very different migratory pathways. Also note that, whereas most subspecies have distinct wintering areas, the closely related piersmai (mainly tropical northwest Australia) and rogersi (mainly New Zealand) show some degree of overlap that may hint at ongoing microevolutionary change

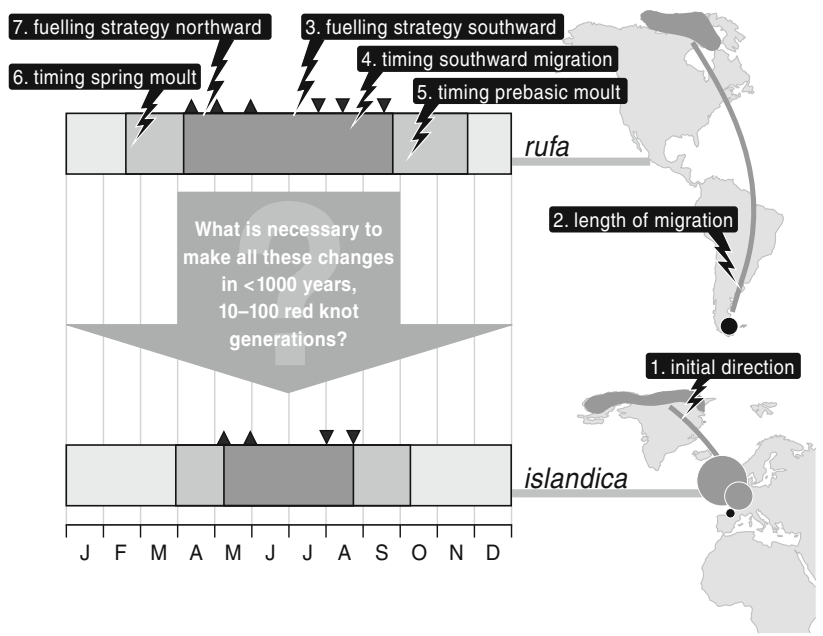

Fig. 2 Contrasts in the migration and annual cycle characteristics of the two most closely related subspecies of Red Knots (rufa and islandica), with a suggestion of seven traits that would have to evolve considerable quantitative and qualitative novelty in the presumed descendent subspecies islandica within a short spell of time (Buehler et al. 2006). The bars show the typical (average) timing of birds carrying a basic plumage (light grey) or the alternate plumage (dark grey) and the timing of moult from one plumage type into the other (medium grey). Also indicated are the timings of northward (upward pointing triangles) and southward (downward pointing triangles) flights; generally three each in rufa and two each in islandica 
Fig. 3 Contrasts in the annual cycle of the most closely related subspecies of Red Knot, rufa and islandica, as reflected in two flexible and seasonally cyclic traits, body mass and the extent of alternate plumage.

Two birds from each subspecies are given. These adult birds lived in small flocks in outdoor aviaries at Royal Netherlands Institute for Sea Research on Texel, The Netherlands, experiencing the local temperature and light regimes
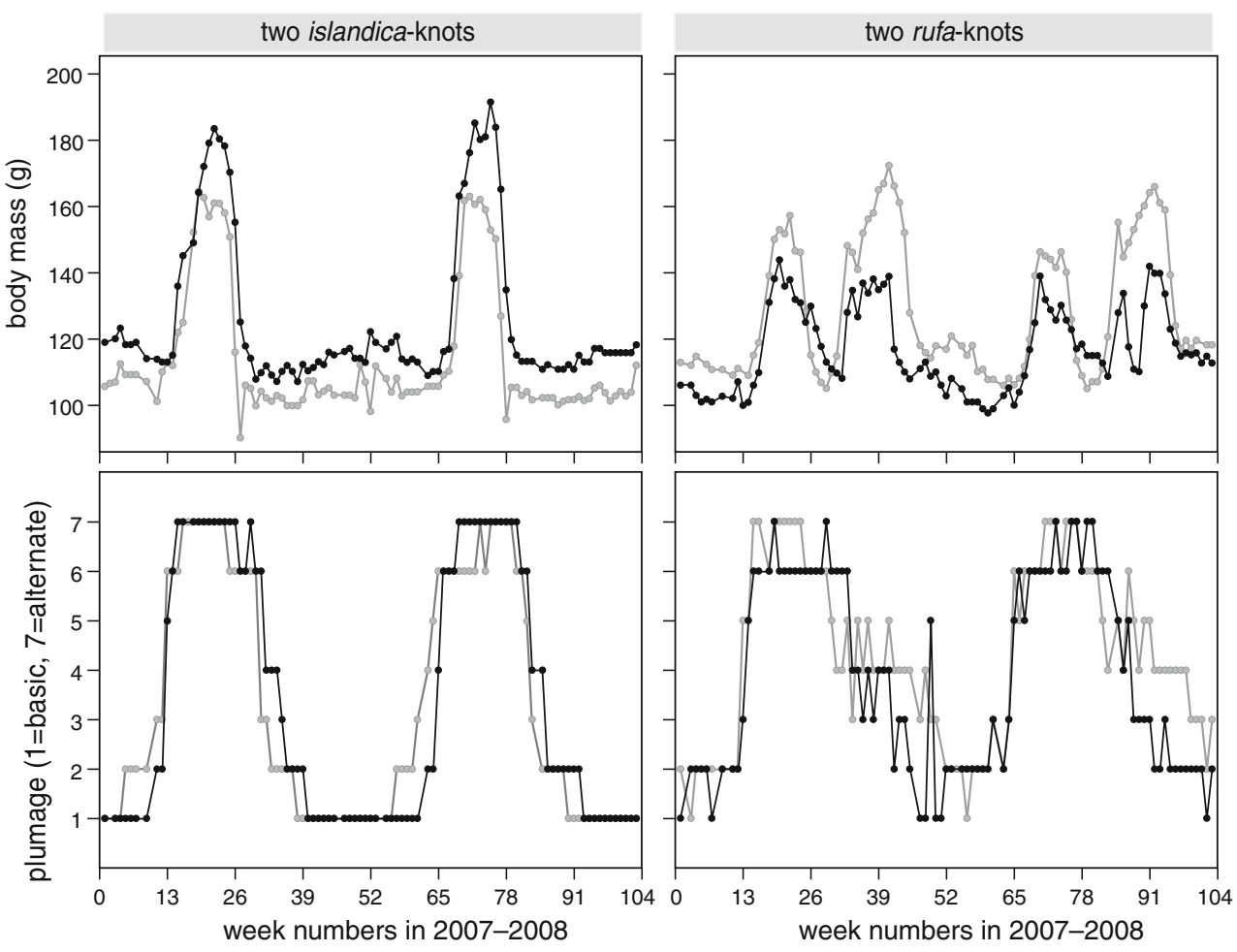

\section{Beyond hard-coding: soft coding and the extended synthesis}

Over the last 100 years, biology has strongly focussed on the two-stage evolutionary process of mutational changes to the genome with downstream consequences for the phenotype on which natural selection operates. This is a relatively slow process, and the finding that rapid phenotypic change commonly occurs in a wide variety of organisms has lead to explanations invoking selection for previously unexpressed (hidden or 'standing') genetic variation (Barrett and Schluter 2008; Le Rouzic and Carlborg 2008). Whilst I cannot dismiss this possibility, I also like to be open to explanations that go beyond the hard-coding of phenotypic traits.

Increasingly, evolutionary biologists appreciate that inheritance pathways other than the transmission of genes play a role in evolution (Jablonka and Lamb 2006; Pigliucci and Müller 2010). Interestingly, these 'soft-coded' inheritance pathways (Fig. 4) would imply considerable interaction and even trans-generational feedbacks between the environment and the phenotype, and this could speed up the ways in which organisms adapt to rapid environmental change (West-Eberhard 2003; Jablonka and Lamb 2006; Turner 2007; Laland et al. 2008; Piersma and van Gils 2011).

The revolution in molecular biology has spawned an enormous research effort to refine the molecular basis of evolutionary change (Bromham 2008). Yet, despite the availability of a wealth of advanced quantitative and molecular genetic techniques and innovative statistical tools (Ellegren and Sheldon 2008; Rice et al. 2011), an understanding of the ways in which genetic change underpin phenotypic change (i.e. the translation from genotype to phenotype) is a long way off (Sheldon 2010). The gene-up approach to the microevolution of bird migration is now yielding the first successes (e.g. Karell et al. 2011; Mueller et al. 2011), but is still far removed from understanding the evolution and maintenance of trait variation. Apart from notable exceptions to do with rare diseases, the detection of DNA variations that explain the phenotype has been frustratingly complex (Dowell et al. 2010). One of the reasons is that non-genetic factors play such an important role in the expression of genotypes (Jablonka and Lamb 2006; Turner 2007). Biology could be enriched by the acknowledgement that non-genetic factors such as developmental processes (expressed as phenotypic plasticity) and learning can affect the generation and maintenance of variation and rapid change of phenotypes (Fig. 5). The explanatory Darwinian ingredients of the Modern Synthesis (Mayr 1963, 1982) no longer suffice (Both 2010; Pigliucci and Müller 2010).

There are various 'soft-coded' ways in which the actual translation into phenotypes of the genetic code in DNA may be blocked or facilitated (Fig. 4). In the cellular epigenetic scenario, the presence or absence of methyl, acetyl or phosphate groups to the DNA or histones can transiently or permanently modify gene expression by altering the local chromatin structure (Johannes et al. 2008; Law and 


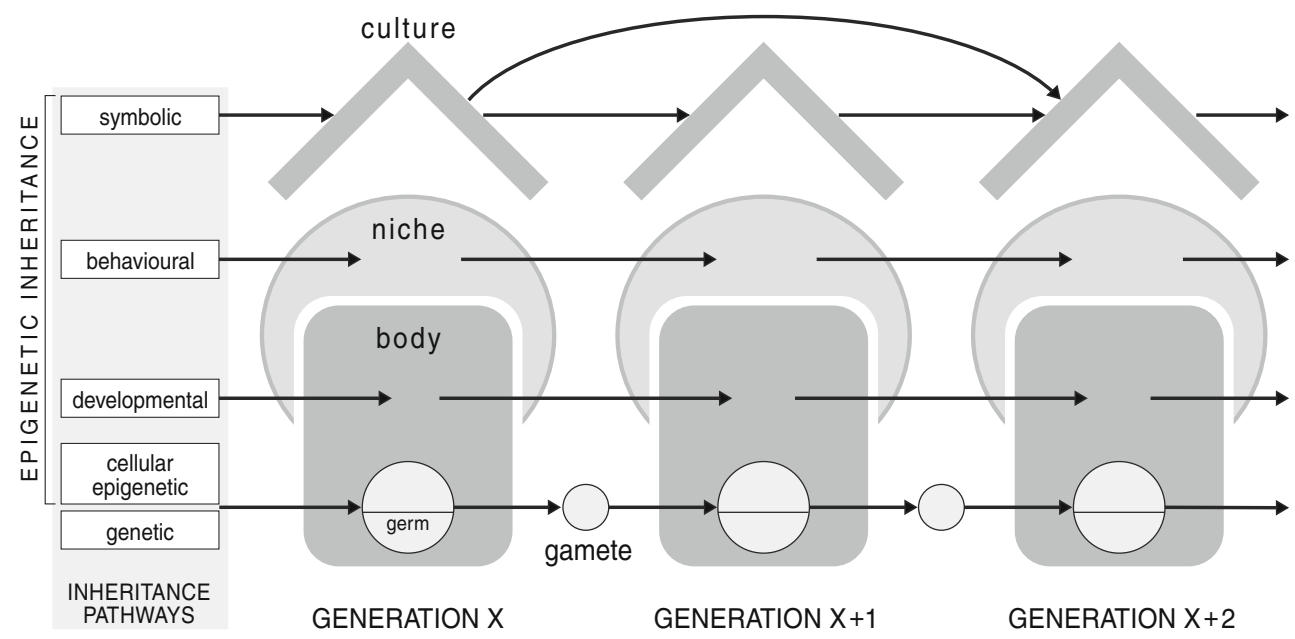

Fig. 4 In addition to the genetic variation transmitted from generation to generation through the germline, there are four additional 'epigenetic' inheritance pathways. The first of those, 'cellular epigenetic inheritance', transmits acquired information via the gametes. The remaining three are all 'somatic' and include 'developmental inheritance' (e.g. through maternal effects), 'behavioural inheritance' (through niche construction), and 'symbolic inheritance'. One of the reasons that it took biologists so long to distinguish these layers is that they are thoroughly intertwined. There is also 'reciprocal causation', especially between niche and body. Note that 'symbolic inheritance' is specific to organisms that read books, watch TV and write grant applications. Of the five possible inheritance pathways of information transfer between generations, two (developmental inheritance and behavioural inheritance) would be especially relevant for the fast evolutionary change of flyways and annual schedules. Developed from Jablonka and Lamb $(2005,2007)$ and adapted after Piersma and van Gils (2011)

Fig. 5 Schematic representation of the key concepts of Darwinism (centre), the Modern Synthesis (intermediate field) and a more extended synthesis of evolutionary explanations (outer ring) of life forms on earth. This scheme, modified after Pigliucci and Müller (2010), aims to show the nearcontinuous expansion of evolutionary theory with new and increasingly non-genetic concepts for mechanisms of change. I propose that an understanding of the evolutionary mechanisms of rapid flyway evolution would require research efforts on phenotypic plasticity and learning

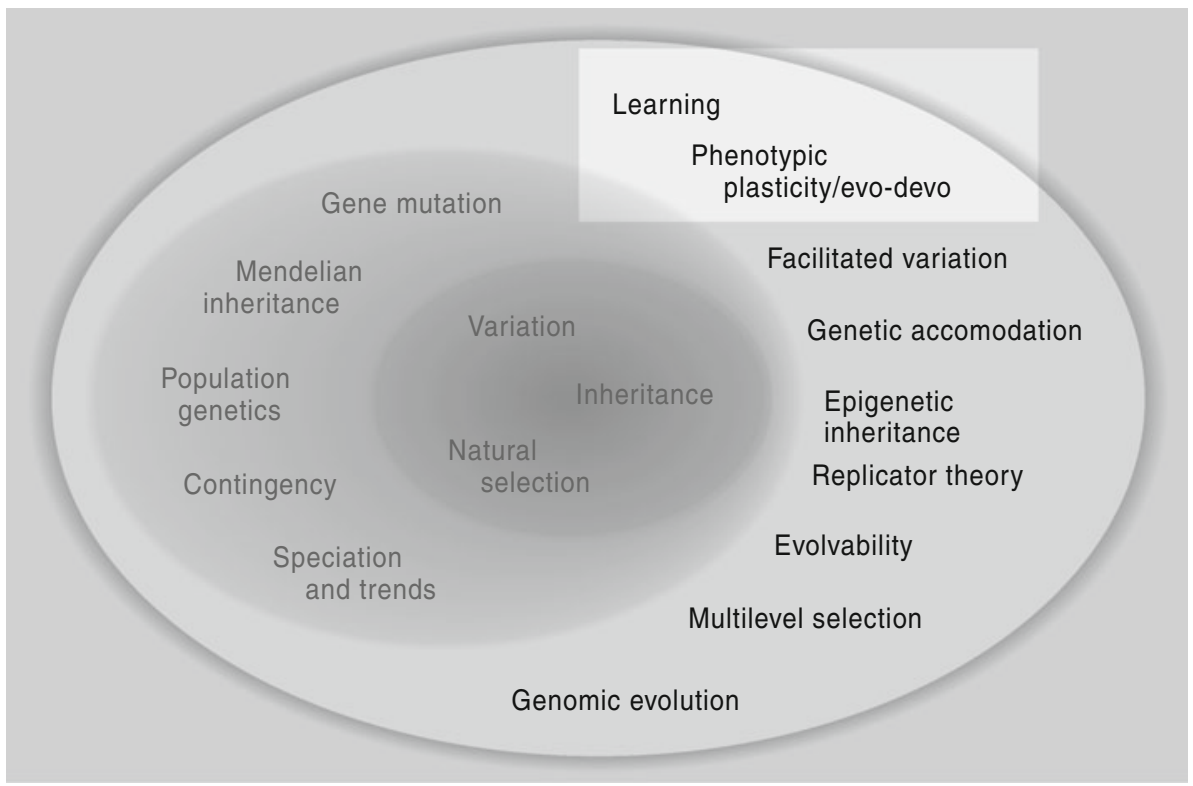

Jacobsen 2009). These cellular epigenetic changes can be induced by environmental and/or genetic factors, and can remain relatively stable over several generations (Teixeira et al. 2009; Reinders et al. 2009). Phenotype can also be changed by mechanisms other than (epi)genome variation (Fig. 4). For example, the physiology of a bird embryo can also be affected by variable levels of maternal hormones, immune factors, etc.; developmental inheritance). Also, young birds can learn the migration route from more experienced birds (behavioural inheritance).

\section{Research opportunities in the anthropocene}

We live in the Anthropocene (Steffen et al. 2007; Kolbert 2011), an era of loss and of opportunity. Our time is one of strong declines in biodiversity (Pereira et al. 2010), yet it is also a time when we can learn from the rapid ongoing changes if we care to look. 'Looking carefully' at global scales is now made possible by the close connections (through internet and cheap airfares) of focussed observers worldwide (e.g. Rakhimberdiev et al. 2011), the availability 
Table 1 Predictions to what will happen to birds translocated across the Atlantic from either the islandica or rufa subspecies of Red Knot, depending on how migration and annual routines are flexibly orchestrated, and whether learning from older birds takes place during early life

\begin{tabular}{|c|c|c|c|c|}
\hline & \multicolumn{2}{|c|}{ islandica moved to Canada } & \multicolumn{2}{|c|}{ rufa moved to Wadden Sea } \\
\hline & As juvenile & As adult & As juvenile & As adult \\
\hline $\begin{array}{l}\text { Fixed circannual } \\
\text { programme } 1\end{array}$ & $\begin{array}{l}\text { Stay in the north } \\
\text { (as in Europe) }\end{array}$ & $\begin{array}{l}\text { Stay in the north } \\
\text { (as in Europe) }\end{array}$ & Fly south with canutus & Fly south with canutus \\
\hline $\begin{array}{l}\text { Fixed circannual } \\
\text { programme } 2\end{array}$ & Return to Europe & Return to Europe & Return to the Americas & Returns to the Americas \\
\hline $\begin{array}{l}\text { Flexible during } \\
\text { early ontogeny }\end{array}$ & Migrate to S. America & $\begin{array}{l}\text { Stay north or return } \\
\text { to Europe }\end{array}$ & $\begin{array}{l}\text { Stay in Europe or fly } \\
\text { south with canutus }\end{array}$ & $\begin{array}{c}\text { Fly south with canutus } \\
\text { or return to America }\end{array}$ \\
\hline Fully flexible & Migrate to S. America & Migrate to S. America & $\begin{array}{c}\text { Stay in Europe or fly } \\
\text { south with canutus }\end{array}$ & $\begin{array}{l}\text { Stay in Europe or fly } \\
\text { south with canutus }\end{array}$ \\
\hline
\end{tabular}

For the predictions for 'fixed circannual programmes', we listed the scenario where Red Knots after displacement know latitude, but not longitude (possibility 1), or know precisely where they are with respect to where they come from (possibility 2)

of capture-recapture datasets spanning several generations of birds (van der Jeugd et al. 2009), and by the possibility to examine survival and dispersal using an amazing array of remote sensing and tracking tools (Robinson et al. 2010). Even for small organisms that travel the world, such as Red Knots, the tools are now available to track their survival and movements across the globe with considerable spatial and temporal precision.

Building on the ongoing demographic studies assembled within a worldwide collaborative research network with a particular emphasis on individually colour-ringing Red Knots and other shorebirds and resighting them (Global Flyway Network; see Piersma 2007), comparative analyses can be done of dispersal and survival based on sample sizes of several thousands individually marked Red Knots and multiple resightings of many of these individuals (e.g. Baker et al. 2004; Leyrer et al. 2011). Recent advances in multistate modelling (Lebreton et al. 2009) should enable the estimation of variation in survival rates over several generations within and between flyways and also obtain estimates of dispersal rates. In the case of the best studied Red Knot subspecies rufa, islandica and canutus, this would yield estimates of vital rates and dispersal during periods of habitat decline and restoration (Baker et al. 2004; Kraan et al. 2009) and thus enable us to examine the demographic drivers of micro-evolution.

\section{Phenotypic experimentation}

Recent observations suggest that individual Red Knots (rufa as well as islandica) may sometimes switch flyways. This indicates that individual flexibility of flyway use is higher than we have assumed so far. An adult Red Knot marked in northern Norway (presumably islandica) was resighted a year later in the Mingan Archipelago, in the
Gulf of St. Lawrence, Canada. Another bird marked at Mingan (presumably rufa) had moved to Iceland 2 years after marking (Wilson et al. 2010). Given the highly sociable behaviour of this species, individuals may be tuned by the behaviour of group members (Helm et al. 2006), enabling them to successfully switch between flyways.

I suggest that we could find out about the degrees of flexibility, and the epigenetic mechanisms involved (Fig. 4), by carrying out two types of phenotypic experiments: (1) bring birds together in common environments (common garden experiments), and (2) displacing birds to new conditions (translocation experiments). Building on preliminary results reported in Fig. 3, bringing birds from different flyways under identical environmental conditions would allow us to examine the degree that the seasonally changing phenotypes are (in-)flexible for genetic and nongenetic reasons, or whether the birds can adjust to alternative photoperiodic regimes. If the degree of adjustment is age-dependent, this would additionally tell us if social learning is involved.

The common garden experiments should be complemented by experiments 'in the wild'. In the 1950s and 1960s, Perdeck and collaborators translocated 15,000 Starlings Sturnus vulgaris and 1,250 Chaffinches Fringilla coelebs from The Netherlands to Switzerland and 3,500 Starlings to Spain in what is now one of the most classic series of experiments in the study of bird migration (Perdeck 1958, 1967, 1974). We could fit birds with small solar-energized satellite tags and reciprocally translocate them between flyways. To show the scope for testing explicit evolutionary/developmental hypotheses of such phenotypic experimentation, I have worked out a case where young and old rufa and islandica Knots are reciprocally displaced between the staging areas on southward migration (Table 1). We can use the contrast between 
juveniles and adults to see whether having experienced one or more full migration cycles affects the capacity to adjust flexibly to a new situation and fly with the 'receiving' flocks at the new location, or whether the routines have become fixed with respect to phenotypic change and migration.

Thus, by including young and older birds in the experiment, we can address the role of age-dependent behavioural inheritance, i.e. learning, on the expectation that, in their first year, learning phenotypes would still be able to adjust phenotypically to new regimes, whereas older birds might not (Sutherland 1998). Fully flexible individuals will move with their new flocks, and even adjust the timing of fuelling and moult. If this were to occur, we have to explain an interesting contrast with the results from the preliminary aviary experiments (Fig. 3). Such flexibility would be at variance with the idea that the divergent traits have a rigid genetic background and would emphasize the creative force of two-way interactions between organisms and their environment (Laland et al. 2008).

Acknowledgments The ideas presented here developed slowly over many years during discussions with Allan J. Baker, Ritsert Jansen, Deborah M. Buehler, Yvonne I. Verkuil, Franjo Weissing, David W. Winkler, Christiaan Both, Robert E. Gill, T. Lee Tibbitts, Bob Ricklefs, Hugh Boyd, Eva Jablonka, Barbara Helm, Andreas Helbig, Robert Zink, and many others. I am grateful to Franz Bairlein for providing the opportunity to present these ideas at the Centennial Symposium of the Vogelwarte Helgoland, and for his patient prompting to actually get a manuscript. Maarten Brugge was responsible for the husbandry of, and data collection on, the captive Red Knots, Dick Visser drew the figures, and Yvonne Verkuil and Eldar Rakhimberdiev provided constructive comments on the manuscript.

Open Access This article is distributed under the terms of the Creative Commons Attribution Noncommercial License which permits any noncommercial use, distribution, and reproduction in any medium, provided the original author(s) and source are credited.

\section{References}

Able KP, Belthoff JR (1998) Rapid 'evolution' of migratory behaviour in the introduced house finch of eastern North America. Proc R Soc Lond B 265:2063-2071

Alerstam T, Hedenström A, Åkesson S (2003) Long-distance migration: evolution and determinants. Oikos 103:247-260

Badyaev AV (2011a) Origin of the fittest: link between emergent variation and evolutionary change as a critical question in evolutionary biology. Proc R Soc Lond B. doi:10.1098/rspb. 2011.0548

Badyaev AV (2011b) How do precise adaptive features arise in development? Evolution of context-specific sex-ratios and perfect beaks. Auk (in press)

Baker AJ, González PM, Piersma T, Niles LJ, de Lima S, do Nascimento I, Atkinson PW, Collins P, Clark NA, Minton CDT, Peck MK, Aarts G (2004) Rapid population decline in Red Knots: fitness consequences of decreased refuelling rates and late arrival in Delaware Bay. Proc R Soc Lond B 271:875-882
Barrett RDH, Schluter D (2008) Adaptation from standing genetic variation. Trends Ecol Evol 23:38-44

Battley PF, Piersma T (2005) Adaptive interplay between feeding ecology and features of the digestive tract in birds. In: Starck JM, Wang $\mathrm{T}$ (eds) Physiological and ecological adaptations to feeding in vertebrates. Science Publishers, USA, pp 201-228

Battley PF, Piersma T, Dietz MW, Tang S, Dekinga A, Hulsman K (2000) Empirical evidence for differential organ reductions during trans-oceanic bird flight. Proc $\mathrm{R}$ Soc Lond $\mathrm{B}$ 267:191-196

Berthold P (1995) Microevolution of migratory behaviour illustrated by the Blackcap Sylvia atricapilla: 1993 Witherby lecture. Bird Study 42:89-100

Berthold P, Querner U (1981) Genetic basis of migratory behaviour in European warblers. Science 212:77-79

Both C (2010) Flexibility of timing of avian migration to climate change masked by environmental constraints en route. Curr Biol 20:243-248

Bromham L (2008) Reading the story in DNA. A beginner's guide to molecular evolution. Oxford University Press, Oxford

Buehler DM, Baker AJ (2005) Population divergence times and historical demography in red knots and dunlins. Condor 107:497-513

Buehler DM, Piersma T (2008) Travelling on a budget: predictions and ecological evidence for bottlenecks in the annual cycle of long-distance migrants. Philos Trans R Soc Lond B 363:247-266

Buehler DM, Baker AJ, Piersma T (2006) Reconstructing palaeoflyways of the late pleistocene and early holocene red knot (Calidris canutus). Ardea 94:485-498

Buehler DM, Piersma T, Tieleman BI (2008a) Captive and free-living red knots Calidris canutus exhibit differences in non-induced immunity that suggest different immune strategies in different environments. J Avian Biol 39:560-566

Buehler DM, Matson KD, Piersma T, Tieleman BI (2008b) Seasonal redistribution of immune function in a shorebird: annual-cycle effects override adjustments to thermal regime. Am Nat 172:783-796

Buehler DM, Tieleman BI, Piersma T (2009) Age and environment affect constitutive immune function in red knots (Calidris canutus). J Ornithol 150:815-825

Dowell RD et al (2010) Genotype to phenotype: a complex problem. Science 328:469

Ellegren H, Sheldon BC (2008) Genetic basis of fitness differences in natural populations. Nature 452:169-175

Engelmoer M, Roselaar CS (1998) Geographical variation in waders. Kluwer, Dordrecht

Gill RE Jr, Tibbitts TL, Douglas DC, Handel CM, Mulcahy DM, Gottschalck JC, Warnock N, McCaffery BJ, Battley PF, Piersma $T$ (2009) Extreme endurance flights by landbirds crossing the Pacific Ocean: ecological corridor rather than barrier? Proc R Soc Lond B 276:447-457

Haldane JBS (1957) The cost of natural selection. J Gen 55:511-524

Helbig AJ (2003) Evolution of migration: a phylogenetic and biogeographic perspective. In: Berthold P, Gwinner E, Sonnenschein E (eds) Avian migration. Springer, Heidelberg, pp 3-20

Helm B, Piersma T, van der Jeugd HP (2006) Sociable schedules: interplay between avian seasonal and social behaviour. Anim Behav 72:245-262

Jablonka E, Lamb MJ (2005) Evolution in four dimensions: genetic, epigenetic, behavioral and symbolic variation in the history of life. MIT Press, Cambridge

Jablonka E, Lamb MJ (2006) The evolution of information in the major transitions. J Theor Biol 239:236-246

Jablonka E, Lamb MJ (2007) The expanded evolutionary synthesisa response to Godfrey-Smith, Haig, and West-Eberhard. Biol Philos 22:453-472 
Johannes F, Colot V, Jansen RC (2008) Epigenome dynamics: a quantitative genetics perspective. Nat Rev Gen 9:883-890

Karell P, Ahola K, Karstinen T, Valkama J, Brommer JE (2011) Climate change drives microevolution in a wild bird. Nat Comm 2(208). doi:10.1038/ncomms1213

Kolbert E (2011) Enter the anthropocene: age of man. Natl Geogr Mag 219:60-85

Kraan C, van Gils JA, Spaans B, Dekinga A, Bijleveld AI, van Roomen M, Kleefstra R, Piersma T (2009) Landscape-scale experiment demonstrates that Wadden Sea intertidal flats are used to capacity by molluscivore migrant shorebirds. J Anim Ecol 78:1259-1268

Laland KN, Odling-Smee J, Gilbert SF (2008) EvoDevo and niche construction: building bridges. J Exp Zool 310B:549-566

Law JA, Jacobsen SE (2009) Dynamic DNA methylation. Science 323:1568-1569

Le Rouzic A, Carlborg Ö (2008) Evolutionary potential of hidden genetic variation. Trends Ecol Evol 23:33-37

Lebreton JD, Nichols JD, Barker RJ, Pradel R, Spendelow JA (2009) Modeling individual animal histories with multistate capturerecapture models. Adv Ecol Res 41:87-173

Leyrer J, Brugge M, Spaans B, Lok T, Sandercock BK, Piersma T (2011) Seasonal survival rates of a migratory shorebird suggest tropical wintering is riskier than migration. Proc R Soc Lond B (in press)

Mayr E (1963) Animal species and evolution. Belknap, Cambridge

Mayr E (1982) The growth of biological thought. Diversity, evolution, and inheritance. Harvard University Press, Cambridge

Mueller JC, Pulido F, Kempenaers B (2011) Identification of a gene associated with avian migratory behaviour. Proc R Soc Lond B. doi:10.1098/rspb.2010.2567

Nunney L (2003) The cost of natural selection revisited. Ann Zool Fenn 40:185-194

Outlaw DC, Voelker G, Mila B, Girman DJ (2003) Evolution of longdistance migration in and historical biogeography of Catharus thrushes: a molecular phylogenetic approach. Auk 120:299-310

Perdeck AC (1958) Two types of orientation in migrating starlings, Sturnus vulgaris L., and chaffinches, Fringilla coelebs L., as revealed by displacement experiments. Ardea 46:1-37

Perdeck AC (1967) Orientation of starlings after displacement to Spain. Ardea 55:194-202

Perdeck AC (1974) An experiment on the orientation of juvenile starlings during spring migration. Ardea 62:190-195

Pereira HM et al (2010) Scenarios for global biodiversity in the 21st century. Science 330:1496-1501

Piersma T (2002) When a year takes 18 months: evidence for a strong circannual clock in a shorebird. Naturwissenschaften 89:278279

Piersma T (2007) Using the power of comparison to explain habitat use and migration strategies of shorebirds worldwide. J Ornithol 148(Suppl. 1):S45-S59

Piersma T, van Gils JA (2011) The flexible phenotype: a body-centred integration of ecology, physiology, and behaviour. Oxford University Press, Oxford

Piersma T, Wiersma P (1996) Family Charadriidae (plovers). In: del Hoyo J, Elliott A, Sargatal J (eds) Handbook of the birds of the world, Hoatzin to Auks, vol 3. Lynx, Barcelona, pp 384-442

Piersma T, van Gils J, Wiersma P (1996) Family Scolopacidae (sandpipers, snipes and phalaropes). In: del Hoyo J, Elliott A, Sargatal J (eds) Handbook of the birds of the world, Hoatzin to Auks, vol 3. Lynx, Barcelona, pp 444-533

Piersma T, Gudmundsson GA, Lilliendahl K (1999) Rapid changes in the size of different functional organ and muscle groups during refueling in a long-distance migrating shorebird. Physiol Biochem Zool 72:405-415
Piersma T, Rogers DI, González PM, Zwarts L, Niles LJ, do Nascimento I, Minton CDT, Baker AJ (2005) Fuel storage rates in Red Knots worldwide: facing the severest ecological constraint in tropical intertidal conditions? In: Greenberg R, Marra PP (eds) Birds of two worlds: the ecology and evolution of migratory birds. Johns Hopkins University Press, Baltimore, pp 262-274

Piersma T, Brugge M, Spaans B, Battley PF (2008) Endogenous circannual rhythmicity in body mass, molt, and plumage of great knots Calidris tenuirostris. Auk 125:140-148

Pigliucci M, Müller GB (eds) (2010) Evolution: the extended synthesis. MIT Press, Cambridge

Pulido F (2007) The genetics and evolution of avian migration. Bioscience 57:165-174

Pulido F, Berthold P (2010) Current selection for lower migratory activity will drive the evolution of residency in a migratory bird population. Proc Natl Acad Sci USA 107:7341-7346

Rakhimberdiev E, Verkuil YI, Saveliev AA, Väisänen RA, Karagicheva J, Soloviev MY, Tomkovich PS, Piersma T (2011) A global population redistribution in a migrant shorebird detected with continent-wide qualitative breeding survey data. Divers Distr 17:144-151

Rappole JH, Helm B, Ramos MA (2003) An integrative framework for understanding the origin and evolution of avian migration. J Avian Biol 34:124-128

Reinders J et al (2009) Compromised stability of DNA methylation and transposon immobilization in mosaic Arabidopsis epigenomes. Genes Dev 23:939-950

Reneerkens J, Piersma T, Sinninghe Damsté JS (2007) Expression of annual cycles in preen wax composition in red knots: constraints on the changing phenotype. J Exp Zool 307A:127-139

Rice AM, Rudh A, Ellegren H, Qvarnström A (2011) A guide to the genomics of ecological speciation in natural animal populations. Ecol Lett 14:9-18

Robinson RW, Bowlin MS, Bisson I, Shamoun-Baranes J, Thorup K, Diehl RH, Kunz TH, Mabey S, Winkler DW (2010) Integrating concepts and technologies to advance the study of bird migration. Front Ecol Environ 8:354-361

Salewski V, Bruderer B (2007) The evolution of bird migration-a synthesis. Naturwissenschaften 94:268-279

Sheldon BC (2010) Genetic perspectives on the evolutionary consequences of climate change in birds. In: Møller AP, Fiedler W, Berthold P (eds) Effects of climate change on birds. Oxford University Press, Oxford, pp 149-168

Steffen W, Crutzen PJ, McNeill JR (2007) The Anthropocene: are humans now overwhelming the great forces of nature? Ambio 36:614-621

Sutherland WJ (1998) Evidence for flexibility and constraint in migration systems. J Avian Biol 29:441-446

Teixeira FK et al (2009) A role for RNAi in the selective correction of DNA methylation defects. Science 323:1600-1604

Tomkovich PS (1992) An analysis of the geographic variability in Knots Calidris canutus based on museum skins. Wader Study Group Bull 64:17-23

Tomkovich PS (2001) A new subspecies of red knot Calidris canutus from the New Siberian Islands. Bull Ornithol Club 121:257-263

Turner JS (2007) The tinkerer's accomplice. How design emerges from life itself. Harvard University Press, Cambridge

van der Jeugd HP, Eichhorn G, Litvin KE, Stahl J, Larsson K, van der Graaf AJ, Drent RH (2009) Keeping up with early springs: rapid range expansion in an avian herbivore incurs a mismatch between reproductive timing and food supply. Glob Change Biol 15:1057-1071

van Noordwijk AJ, Pulido F, Helm B, Coppack T, Delingat J, Dingle $\mathrm{H}$, Hedenström A, van der Jeugd $\mathrm{H}$, Marchetti C, Nilsson A, 
Perez-Tris J (2006) A framework for the stury of genetic variation in migratory behaviour. J Ornithol 147:221-233

Vézina F, Jalvingh KM, Dekinga A, Piersma T (2006) Acclimation to different thermal conditions in a northerly wintering shorebird is driven by body mass-related changes in organ size. J Exp Biol 209:3141-3154

Vézina F, Dekinga A, Piersma T (2010) Phenotypic compromise in the face of conflicting ecological demands: an example in red knots Calidris canutus. J Avian Biol 41:88-93
West-Eberhard MJ (2003) Developmental plasticity and evolution. Oxford University Press, New York

Wilson J, Aubry Y, Buidin C, Rochepault Y, Baker AJ (2010) Three records of red knots Calidris canutus possibly changing flyways. Wader Study Group Bull 117:192-193

Zink RM (2002) Towards a framework for understanding the evolution of avian migration. J Avian Biol 33:433-436 